\title{
STUDIES ON CALCIUM CONTENT IN SEA WATER. III. CALCIUM IN THE WATERS OF CANANÉIA LAGOON AND ITS ADJACENT REGIONS, STATE OF SÃO PAULO, BRAZIL
}

\author{
(Received for publication in 1959)
}

\author{
Kenji Kato * \\ Faculty of Fisheries, Hokkaido University - Japan \\ Oceanographic Institute, University of São Paulo - Brazil
}

\begin{abstract}
SYNOPSIS
In this paper a series of geochemical investigations are reported with respect to calcium contents in different waters collected from the sea off the coast of Cananéia, the lagoon surrounding Cananéia Island and from Nóbrega river (one of the saline branches from the lagoon, also called "marigot").

An almost direct relation of calcium to chlorinity, 0.02168 in average, similar to that of the outer Atlantic water, 0.02156, was observed in the coastal water. This indicates that the terrigenous supply of calcium might not contribute very much to the calcium content in the coastal water.

The inflow of land water to the lagoon of Cananéia does not increase the calcium content of the lagoon water, where a slight depression of the $\mathrm{Ca} / \mathrm{Cl}$ gradient (namely 0.0206) was observed. This characteristic of the calcium distribution is more remarkable in the water of the "marigot", branching off from the lagoon. An extremely low gradient of calcium to chlorinity, 0.0177 is one of the geochemical characteristics found in tropical estuaries where active bacterial decomposition of deposited organic materials renders the geochemical properties of the water more acid and more reduced.

The low content of calcium in land water, $4-6 \mathrm{mg} / \mathrm{Ca} / \mathrm{kg}$, has also of course, a close relationship to this peculiar aspect of the calcium distribution in the coastal water, and further in the Atlantic water off the Brazilian coast.
\end{abstract}

\section{INTRODUCTION}

After having studied calcium oceanochemically in the Atlantic Ocean off Brazil (Kato, 1966a) the author studied the calcium contents in the waters of the lagoon of Cananéia and its adjacent region in the southern coast of São Paulo State, Brazil.

The lagoon of Cananéia comprises several beltlike channels, extending over $110 \mathrm{~km}$ from the "Barra do Ararapira" (entrance to the Ararapira Channel) or the western end, to "Foz do Ribeira de Iguape" (Estuary of the Ribeira de Iguape River), or the eastern end. Of these channels, the principal region of research is the ring-like channel surrounding "Ilha de Cananéia" (Cananéia Island) (Besnard, 1950).

Periodical observations were made from November of 1957 to 1958 on the geochemistry of the lagoon. The hydrographical condition of the lagoon

* At present in the Faculty of Fisheries, Prefectural University of Mie, Tsu, Japan. is controlled by the tidal movement of the water and by the dilution with fresh water which runs into the lagoon from the nearby watershed. The coastal wind prevailing in the region sometimes modifies the hydrographical conditions. The saline water channels which branch off from the lagoon are called "marigots" (BESNARD, 1950) because of their geographical characteristics. Chemically the water of these channels is characterized by a very acid medium, near to $\mathrm{pH} 5$, and by a developed reductioncondition due to active decomposition of deposited organic materials (KATO, 1966b).

The oceanographic condition off the coast of Cananéia was periodically observed by the Section of Physical Oceanography (EmiLsson, unpublished) from the Oceanographic Institute, University of São Paulo.

The present paper reports the results of a series of geochemical investigations referring to the calcium contents in the waters collected respectively from 
the sea off Cananéia (I), the lagoon of Cananéia (II) and river Nóbrega (III) one of the "marigots" which branches off from the lagoon.

\section{EXPERIMENTS}

1. Calcium in the coastal water off Cananéia

The calcium content was determined chelatometrically in ten water samples collected from the sea off the coast of Cananéia by the staff of 'Emília', the Institute's research vessel on the $10^{\text {th }}$ of May 1958.
Table $I$ is a list of the analytical data obtained from the samples. The averaged ratio of calcium to chlorinity, 0.02168 , in the coastal water is almost analogous to that in off-shore Atlantic water, 0.02156, as was estimated in another paper (KATO, 1966a). This feature of calcium distribution near the coast seems strange when compared with what has been commonly reported by many researchers, who emphasize the remarkable contribution of terrigenous calcium to the calcium content of the coastal water. Further investigation of the lagoon water is intended for the purpose of explaining this strange aspect of calcium distribution in these coastal waters.

TABLE I - Calcium in the sea water off Cananéia

\begin{tabular}{|c|c|c|c|c|c|c|}
\hline Station * & Depth (m) & Temp. $\left({ }^{\circ} \mathrm{C}\right)$ & $\mathrm{Cl}(\%)$ & $\mathrm{O}_{2}(\mathrm{ml} / \mathrm{L})$ & $\mathrm{Ca} \quad(\mathrm{mg} / \mathrm{kg})$ & $\mathrm{Ca} / \mathrm{Cl}\left(\times 10^{-3}\right)$ \\
\hline I & $\begin{array}{r}0 \\
7 \\
18\end{array}$ & $\begin{array}{l}24.69 \\
24.00 \\
24.08\end{array}$ & $\begin{array}{l}15.29 \\
18.15 \\
18.73\end{array}$ & $\begin{array}{l}5.74 \\
4.915 \\
4.665\end{array}$ & $\begin{array}{l}335 \\
392 \\
406\end{array}$ & $\begin{array}{l}21.92 \\
21.59 \\
21.69\end{array}$ \\
\hline II & $\begin{array}{r}0 \\
7 \\
18\end{array}$ & $\begin{array}{l}25.20 \\
24.19 \\
24.00\end{array}$ & $\begin{array}{l}16.13 \\
18.40 \\
19.055\end{array}$ & $\begin{array}{l}5.945 \\
5.335 \\
4.345\end{array}$ & $\begin{array}{l}354 \\
403 \\
411\end{array}$ & $\begin{array}{l}21.92 \\
21.91 \\
21.56\end{array}$ \\
\hline III & $\begin{array}{r}0 \\
7 \\
15 \\
28\end{array}$ & $\begin{array}{l}24.68 \\
24.00 \\
23.81 \\
23.68\end{array}$ & $\begin{array}{l}16.77 \\
18.495 \\
19.045 \\
19.43\end{array}$ & $\begin{array}{l}5.08 \\
5.135 \\
5.16 \\
4.70\end{array}$ & $\begin{array}{l}353 \\
403 \\
413 \\
421\end{array}$ & $\begin{array}{l}21.06 \\
21.79 \\
21.69 \\
21.64\end{array}$ \\
\hline 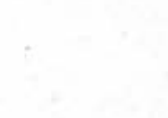 & & $\begin{array}{l}\text { Station I } \\
\text { Station II } \\
\text { Station III }\end{array}$ & $\begin{array}{l}-\quad 25^{\circ} 07.9^{\prime} \mathrm{S} \\
-\quad 25^{\circ} 09.5^{\prime} \mathrm{S} \\
-\quad 25^{\circ} 08.4^{\prime} \mathrm{S}\end{array}$ & $\begin{array}{l}-47^{\circ} 48.4^{\prime} \mathrm{W} \\
-\quad 47^{\circ} 35.7^{\prime} \mathrm{W} \\
-\quad 47^{\circ} 44.2^{\prime} \mathrm{W}\end{array}$ & & \\
\hline
\end{tabular}

(These samples were collected, May 10, 1958)

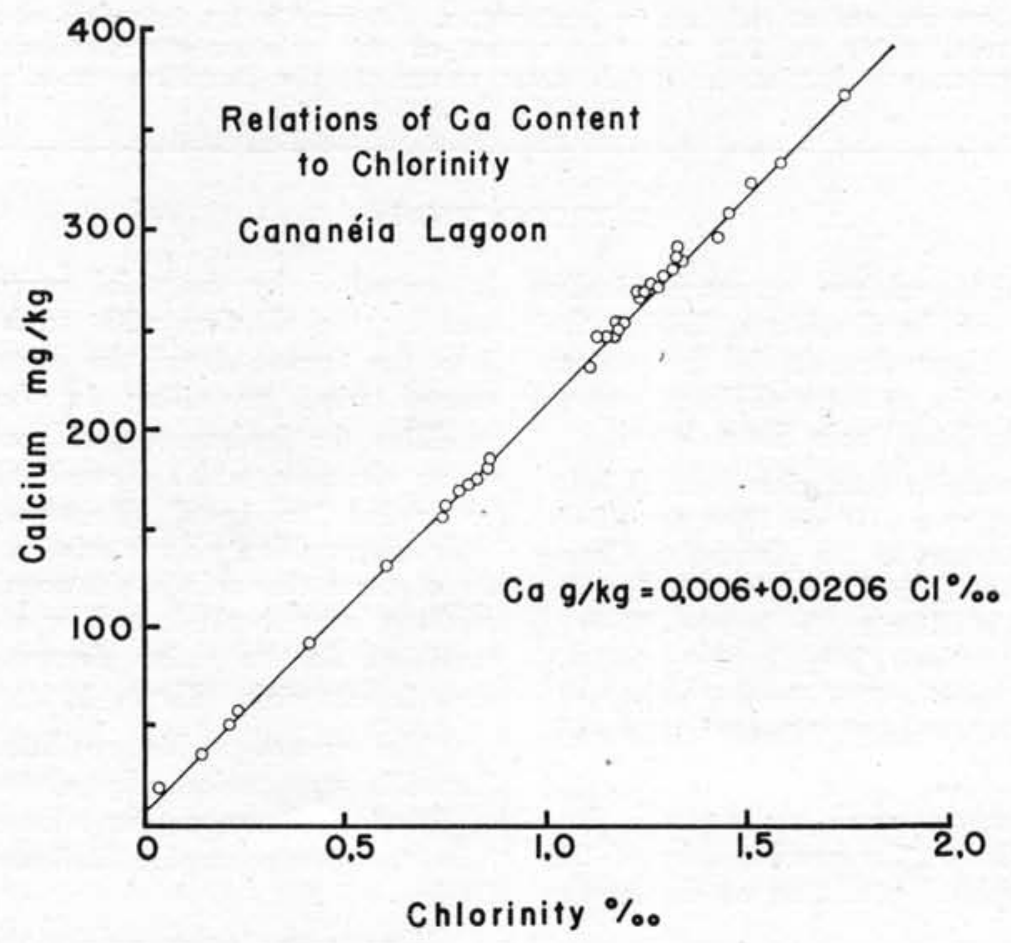

Fig. 1 - Relation of calcium content to chlorinity of the water in Cananéia lagoon. 
2. Calcium in the lagoon water of Cananéia

Determination of calcium was done in 36 water samples, collected during the oceanographic observa- tions on the $10^{\text {th }}$ of May 1958, from 9 stations (KAto 1966c, Fig. 1) in the lagoon surrounding Ilha de Cananéia. These results are given in Table II.

TABLE II - Distribution of calcium in the lagoon of Cananéia (May 10, 1958)

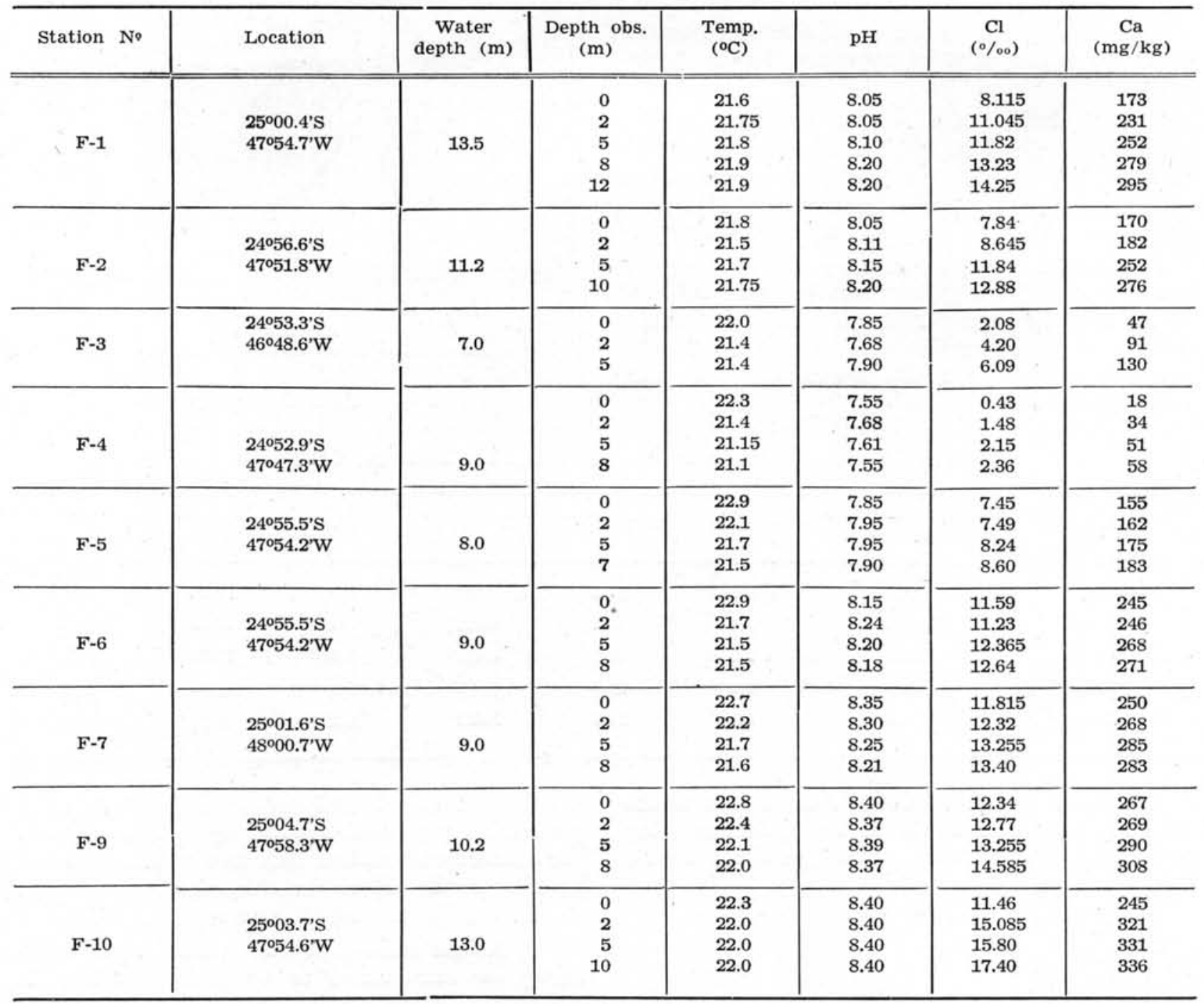

Calcium content in the lagoon water, as illustrated in Figure 2, shows a direct relation to the chlorinity. This aspect of calcium distribution in the lagoon water looks somewhat different from those in common estuarine water, to which a fairly high amount of calcium is usually added by the inflowing land water. Consequently the land water streaming into the lagoon does not increase the amount of calcium in the lagoon water, but merely dilutes the saline water physically which flows into it from the outer sea when the tide rises. The calcium content, approximately $6 \mathrm{mg} \cdot \mathrm{Ca} / \mathrm{kg}$, as extrapolated to $0 \%$ in chlorinity (Figure 1), gives the quantity of calcium in the land water of the watersheds adjacent to the lagoon. In consequence, off the Brazilian coast, mixture of the sea water with the land water will not always contribute to the rise of $\mathrm{Ca} / \mathrm{Cl}$ factor in the coastal water.
It is also noteworthy that the lagoon water gives a rather lower gradient of calcium to chlorinity, 0.0206 , when compared to the oceanic water gradient, 0.02156. This lowering of the gradient in the lagoon water proves that a bio-geochemical precipitation of dissolved calcium takes places. This reducing effect of the $\mathrm{Ca} / \mathrm{Cl}$ factor, as will be mentioned in the succeeding section is very remarkable in the "marigot" water.

\section{Calcium in the "marigot" water}

The "marigot", or the saline branch of the Cananéia Lagoon, has some peculiar characteristics from the geochemical point of view (КАTо, 1966b).

1. The hydrographic features of the system are principally controlled by a hydrodynamical equilibrium between the tidal water from the outer sea 
and the fresh water due to meteorological precipitation as well as to underground water oozing out into the channels.

2. A remarkable reduction condition, prevailing throughout the "marigot", affected by active bacterial decomposition of deposited organic materials. Consequently, the scanty dissolved oxygen, accompanying the biochemical reduction by bacteria limits the development of organisms in the "marigot".

3. Related to the reduced condition, a low value of $\mathrm{pH}(5)$ is likely to be observed throughout the waterway of the "marigot" and probably has influence on the geochemical alteration of the water properties and on the diagnosis of the sediments.

Along the waterway of river Nóbrega, one of the "marigots", five water samples were collected on the $26^{\text {th }}$ of April, 1958 (Figure 2). Calcium contents of these samples were determined chelatometrically, and their results are shown with other observed data in Table III.

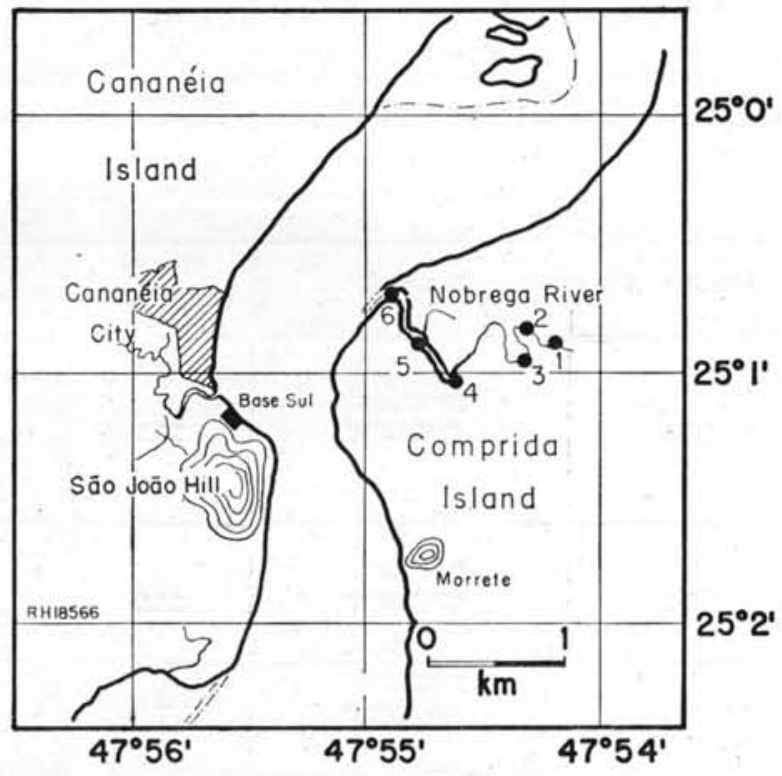

Fig. 2 - Stations in Nóbrega river.

TABLE III - Calcium in the water of river Nóbrega, Cananéia

\begin{tabular}{c|c|c|c|c|c|c|c|c}
\hline Station No & $\begin{array}{c}\text { Distance from the } \\
\text { entrance }(\mathrm{m})\end{array}$ & Depth $(\mathrm{m})$ & Temp. $\left({ }^{\circ} \mathrm{C}\right)$ & $\mathrm{Cl}(\% / \mathrm{oo})$ & $\mathrm{pH}$ & $\begin{array}{c}\mathrm{O}_{2} \begin{array}{c}\text { sat. } \\
(\%)\end{array} \\
(\mathrm{mg} / \mathrm{kg})\end{array}$ \\
\hline \hline $\mathrm{R}-1$ & 2620 & 0.3 & 24.5 & 0.550 & 5.9 & 8.76 & 13.6 \\
$\mathrm{R}-2$ & 2390 & 0.4 & 25.2 & 0.420 & 5.4 & 29.62 & 11.6 \\
$\mathrm{R}-3$ & 1990 & 2.7 & 23.7 & 0.455 & 5.5 & 10.64 & 12.4 \\
$\mathrm{R}-4$ & 1010 & 1.8 & 25.6 & 0.878 & 5.5 & 25.12 & 18.9 \\
$\mathrm{R}-6$ & 60 & 1.7 & 26.3 & 1.650 & 6.2 & 36.14 & 33.2 \\
\hline
\end{tabular}

A direct relation of the calcium content to the chlorinity, as illustrated in Figure 3, is interesting as it shows that the relatively low gradient, 0.0177 ,

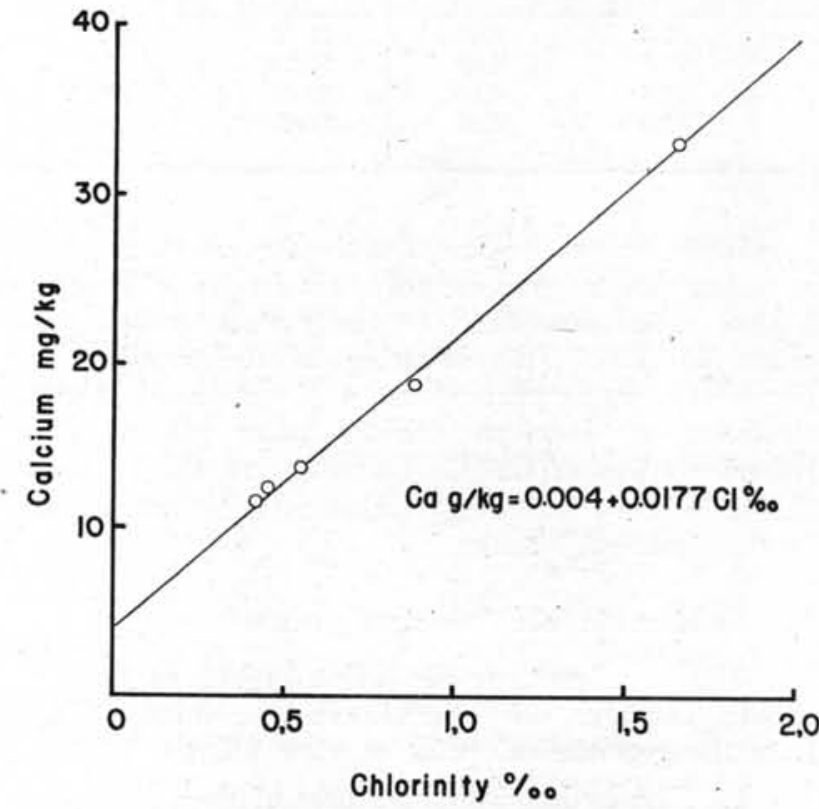

Fig. 3 - Relation of calcium content to chlorinity of the water in Nobrega river. of $\mathrm{Ca}$ to $\mathrm{Cl}$ may be affected by a certain kind of geochemical precipitation occurring in the waterway. The solubility of calcium carbonate reduces with the lowering of the $\mathrm{pH}$ as the chlorinity in the sample decreases (Wattenberg \& Timmermann, 1936).

A definite value of calcium content, about $4 \mathrm{mg}$. $\mathrm{Ca} / \mathrm{kg}$, as extrapolated to $0 \%$ in chlorinity in Figure 3, indicates the approximate quantity of calcium in the fresh water added, and is almost similar to the estimate made for the lagoon water, $6 \mathrm{mg}$. $\mathrm{Ca} / \mathrm{kg}$. In consequence, a calcium content of $4 \cdot 6$ $\mathrm{mg} \cdot \mathrm{Ca} / \mathrm{kg}$ gives the probable quantity of calcium in the land water in relation to the lagoon. KLeEREKOPER (1944) estimated the calcium content in the river waters in São Paulo as approximately 2-4.5 mg-Ca/l. This relatively low content of calcium seems to be one of the geochemical characteristics of Brazilian land water.

\section{R ES UMO}

Neste trabalho relata-se uma série de investigaçōes geoquímicas com respeito ao teor de cálcio em diferentes amostras de água, coletadas no mar diante de Cananéia, na lagoa que circunda a Ilha de Cananéia e no rio Nóbrega (um dos ramos salinos da lagoa, também chamado "marigot"). 
Foi encontrada, nas águas costeiras, uma relação quase direta entre cálcio e clorinidade, 0,02168 em média, similar a 0,02156, para as águas distantes do Atlántico. Isso indica que o suprimento continental de cálcio não deve contribuir muito para o conteúdo de cálcio das águas costeiras.

A entrada de água continental para a lagoa de Cananéia, não aumenta o teor de cálcio das águas da lagoa, onde foi observada ligeira depressão do gradiente $\mathrm{Ca} / \mathrm{Cl}$ (notadamente 0,0206). Essa característica da distribuição do cálcio é mais marcada nas águas do "marigot", o ramo de escoamento da lagoa. Um gradiente extremamente baixo de cálcio para a clorinidade, 0,0177 , é uma das caracteristicas geoquimicas encontradas em estuários tropicais, onde a decomposicão bacteriana ativa dos depósitos de material orgânico estabelece as propriedades das águas mais ácidas e mais reduzidas.

$\mathrm{O}$ baixo teor de cálcio nas águas continentais, 4-6 mg/Ca/kg, tem, por certo, estreita relação com êsse aspecto peculiar da distribuição do cálcio em águas costeiras e também nas águas distantes do Atlântico da costa brasileira.

\section{R E F E R E N C E S}

BESNARD, W. 1950 .

Considerações gerais em tôrno da re-
Bolm Inst. paul. oceanogr., vol. 1, n. $^{\circ}$ 1, p. 9-26.

KATO, K.

1966a. Studies on calcium content in sea water. II. Distribution of calcium in the Atlantic water off South Brazil. Bolm Inst. oceanogr. S Paulo, vol. 15, n. ${ }^{\circ} 1, \mathrm{p}$. 29-39.

1966b. Geochemical studies on the mangrove region of Cananéia, Brazil. II. Physicochemical observations on the reduction states. Bolm Inst. oceanogr. S Paulo, vol. 15, n. $^{\circ} 1$, p. $21-24$.

1966c. Chemical investigations on the hydrographical system of Cananéia lagoon. Bolm Inst. oceanogr. S Paulo, vol. 15, n. ${ }^{\circ}$, p. 1-12.

KLEEREKOPER, $\mathrm{H}$.

1944. Introdução ao estudo da limnologia. Rio de Janeiro, Minist. Agric. Serv. Inform. Agric., 329 p.

Wattenberg, H. \& Timmermann, E.

1936. Ueber die Sattigung des Seewassers an $\mathrm{CaCO}_{3}$. Annln Hydrogr., Berlin, p. 23. 